Article

\title{
Synthesis and Evaluation of Selected Benzimidazole Derivatives as Potential Antimicrobial Agents
}

\author{
Fatmah A. S. Alasmary 1,2,*, Anna M. Snelling ${ }^{2}$, Mohammed E. Zain ${ }^{3}$, Ahmed M. Alafeefy ${ }^{4}$, \\ Amani S. Awaad ${ }^{5}$ and Nazira Karodia ${ }^{2,6, *}$
}

1 Chemistry Department, College of Science, King Saud University, Riyadh 11362, Saudi Arabia

2 Centre for Pharmaceutical Engineering Science, Faculty of Life Sciences, University of Bradford, Richmond Road, Bradford BD7 1DP, UK; E-Mail: a.m.snelling@bradford.ac.uk

3 Botany and Microbiology Department, College of Science, King Saud University, Riyadh 11362, Saudi Arabia; E-Mail: mohamedzain@hotmail.com

4 Department of Pharmaceutical Chemistry, College of Pharmacy, Sattam bin Abdulaziz University, Al-Kharj 11942, Saudi Arabia; E-Mail: alafeefy@hotmail.com

5 Pharmacognosy Department, College of Pharmacy, Salman bin Abdulaziz University, Al-Kharj 11942, Saudi Arabia; E-Mail: amaniawaad@hotmail.com

6 Faculty of Science and Engineering, University of Wolverhampton; Wulfruna Street, Wolverhampton WV1 1LY, UK

* Authors to whom correspondence should be addressed; E-Mails: fasmari@ksu.edu.sa (F.A.S.A.); nazira.karodia@wlv.ac.uk (N.K.); Tel.: +966-506-258-414 (F.A.S.A.); +44-190-232-1920 (N.K.).

Academic Editor: Derek J. McPhee

Received: 28 June 2015 / Accepted: 10 August 2015 / Published: 20 August 2015

\begin{abstract}
A library of 53 benzimidazole derivatives, with substituents at positions 1, 2 and 5, were synthesized and screened against a series of reference strains of bacteria and fungi of medical relevance. The SAR analyses of the most promising results showed that the antimicrobial activity of the compounds depended on the substituents attached to the bicyclic heterocycle. In particular, some compounds displayed antibacterial activity against two methicillin-resistant Staphylococcus aureus (MRSA) strains with minimum inhibitory concentrations (MICs) comparable to the widely-used drug ciprofloxacin. The compounds have some common features; three possess 5-halo substituents; two are derivatives of $(S)$-2-ethanaminebenzimidazole; and the others are derivatives of one 2-(chloromethyl)-1Hbenzo $[d]$ imidazole and $(1 H$-benzo $[d]$ imidazol-2-yl)methanethiol. The results from the antifungal screening were also very interesting: 23 compounds exhibited potent fungicidal
\end{abstract}


activity against the selected fungal strains. They displayed equivalent or greater potency in their MIC values than amphotericin B. The 5-halobenzimidazole derivatives could be considered promising broad-spectrum antimicrobial candidates that deserve further study for potential therapeutic applications.

Keywords: benzimidazole; heterocycle; antibacterial activity; antifungal activity; resistance; Gram-negative; Gram-positive

\section{Introduction}

Microbial drug resistance is a serious issue, especially as increasing numbers of strains are becoming resistant to multiple antimicrobial agents, with some bacteria now being resistant to all available antibiotics. There is thus a critical need to develop new drugs with novel mechanisms of action. However, the investment available for such development is frequently lower than the required level. The development of new drug entities is hampered by several issues, notably the high cost and length of time required, as well as the logistical and regulatory challenges of performing the necessary clinical evaluations across multiple geographical areas. Therefore, a few new classes of antimicrobials have been developed since the late 1980s [1-3], and much research has focused only on the chemical modification of existing drugs to improve their potency and/or ability to overcome antibiotic resistance mechanisms. Even if this approach does not improve antimicrobial activity directly, it may lead to derivatives that can usefully inhibit virulence mechanisms [4].

Compounds having benzimidazole as a structural motif have been widely used in medicinal chemistry and drug development, and researchers are actively seeking new uses and applications of this heterocycle [5]. Benzimidazole-containing compounds have numerous medical and biological activities, such as antitumor [6] antibacterial [7-10], antifungal [11], antiviral [12-16], anticonvulsant [17], antidepressant [18], analgesic [19], anti-inflammatory[20] and antidiabetic properties [21]. For example, derivatives, such as thiabendazole, cambendazole, parbendazole, mebendazole, albendazole and flubendazole, are widely-used anti-helminth drugs, used to treat people and animals with gastrointestinal worm infections [22]. Two groups of benzimidazole derivatives, namely 5,6-dinitro- and 2-trifluromethyl derivatives, are particularly well known for their use as antihelminth drugs [23]. 2-Methoxycarbonylamino derivatives have shown good antiprotozoal activities against some protozoan parasites, such as Giardia lamblia and Entamoeba histolytica, by inhibiting tubulin polymerization, and hence, making these better antiprotozoal agents than metronidazole and albendazole [24]. Nitrogen-containing heterocyclic systems have a diverse spectrum of pharmacological properties. Different heterocyclic motifs can be incorporated to produce molecules with enhanced biological properties. Recent reports include benzimidazoles bearing the 1,3,4-oxadiazole moiety, which have broad spectrum antimicrobial properties [25], and molecules containing both the benzimidazole and indole heterocycles, which exhibit selective antibacterial activity [26].

A review of the literature thus suggests that there is the scope for the design of additional benzimidazole derivatives with antimicrobial activity, by examining the effect of a number of different functional groups.

In this paper, we report on the synthesis of a series of benzimidazole derivatives and their antimicrobial activity. A detailed study of the structure-activity relationship of these derivatives will pave the road to 
designing more potent compounds. The compounds were tested for their ability to inhibit isolates amongst a reference panel of 26 bacterial and 10 fungal strains, and key results are presented in Tables 1-3.

Table 1. Benzimidazole derivatives synthesized.

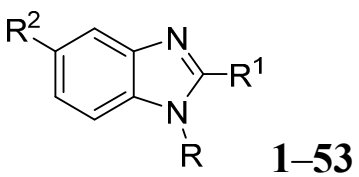

\begin{tabular}{|c|c|c|c|}
\hline Compound & $\mathbf{R}$ & $\mathbf{R}^{1}$ & $\mathbf{R}^{2}$ \\
\hline 1 & $\mathrm{H}$ & $\mathrm{H}$ & $\mathrm{H}$ \\
\hline 2 & $\mathrm{H}$ & $\mathrm{H}$ & $\mathrm{CH}_{3}$ \\
\hline 3 & $\mathrm{H}$ & $\mathrm{H}$ & $\mathrm{OCH}_{3}$ \\
\hline 4 & $\mathrm{H}$ & $\mathrm{H}$ & $\mathrm{Cl}$ \\
\hline 5 & $\mathrm{H}$ & $\mathrm{H}$ & $\mathrm{Br}$ \\
\hline 6 & $\mathrm{H}$ & $\mathrm{H}$ & $\mathrm{F}$ \\
\hline 7 & $\mathrm{H}$ & $\mathrm{H}$ & $\mathrm{NO}_{2}$ \\
\hline 8 & $\mathrm{H}$ & $\mathrm{H}$ & $\mathrm{CN}$ \\
\hline 9 & $\mathrm{H}$ & $\mathrm{CH}_{2} \mathrm{NH}_{2}$ & $\mathrm{H}$ \\
\hline 10 & $\mathrm{H}$ & $\mathrm{CH}_{2} \mathrm{NH}_{2}$ & $\mathrm{CH}_{3}$ \\
\hline 11 & $\mathrm{H}$ & $\mathrm{CH}_{2} \mathrm{NH}_{2}$ & $\mathrm{Cl}$ \\
\hline 12 & $\mathrm{H}$ & $\mathrm{CH}_{2} \mathrm{NH}_{2}$ & $\mathrm{Br}$ \\
\hline 13 & $\mathrm{H}$ & $\mathrm{CH}_{2} \mathrm{NH}_{2}$ & $\mathrm{~F}$ \\
\hline 14 & $\mathrm{H}$ & $\mathrm{CH}_{2} \mathrm{NH}_{2}$ & $\mathrm{NO}_{2}$ \\
\hline 15 & $\mathrm{H}$ & $\mathrm{CH}\left(\mathrm{CH}_{3}\right) \mathrm{NH}_{2}$ & $\mathrm{H}$ \\
\hline 16 & $\mathrm{H}$ & $\mathrm{CH}\left(\mathrm{CH}_{3}\right) \mathrm{NH}_{2}$ & $\mathrm{CH}_{3}$ \\
\hline 17 & $\mathrm{H}$ & $\mathrm{CH}\left(\mathrm{CH}_{3}\right) \mathrm{NH}_{2}$ & $\mathrm{Cl}$ \\
\hline 18 & $\mathrm{H}$ & $\mathrm{CH}\left(\mathrm{CH}_{3}\right) \mathrm{NH}_{2}$ & $\mathrm{Br}$ \\
\hline 19 & $\mathrm{H}$ & $\mathrm{CH}\left(\mathrm{CH}_{3}\right) \mathrm{NH}_{2}$ & $\mathrm{~F}$ \\
\hline 20 & $\mathrm{H}$ & $\mathrm{CH}_{2} \mathrm{CH}_{3}$ & $\mathrm{H}$ \\
\hline 21 & $\mathrm{H}$ & $\mathrm{CH}_{2} \mathrm{CH}_{3}$ & $\mathrm{NO}_{2}$ \\
\hline 22 & $\mathrm{H}$ & $\mathrm{CH}_{2} \mathrm{SH}$ & $\mathrm{H}$ \\
\hline 23 & $\mathrm{H}$ & $\mathrm{CH}_{2} \mathrm{SH}$ & $\mathrm{NO}_{2}$ \\
\hline 24 & $\mathrm{H}$ & $\mathrm{CH}_{2} \mathrm{OH}$ & $\mathrm{H}$ \\
\hline 25 & $\mathrm{H}$ & $\mathrm{CH}_{2} \mathrm{OH}$ & $\mathrm{CH}_{3}$ \\
\hline 26 & $\mathrm{H}$ & $\mathrm{CH}_{2} \mathrm{OH}$ & $\mathrm{OCH}_{3}$ \\
\hline 27 & $\mathrm{H}$ & $\mathrm{CH}_{2} \mathrm{OH}$ & $\mathrm{Cl}$ \\
\hline 28 & $\mathrm{H}$ & $\mathrm{CH}_{2} \mathrm{OH}$ & $\mathrm{Br}$ \\
\hline 29 & $\mathrm{H}$ & $\mathrm{CH}_{2} \mathrm{OH}$ & $\mathrm{F}$ \\
\hline 30 & $\mathrm{H}$ & $\mathrm{CH}_{2} \mathrm{OH}$ & $\mathrm{NO}_{2}$ \\
\hline 31 & $\mathrm{H}$ & $\mathrm{CH}_{2} \mathrm{OH}$ & $\mathrm{CN}$ \\
\hline 32 & $\mathrm{H}$ & $\mathrm{CH}_{2} \mathrm{Cl}$ & $\mathrm{H}$ \\
\hline 33 & $\mathrm{H}$ & $\mathrm{CH}_{2} \mathrm{Cl}$ & $\mathrm{CH}_{3}$ \\
\hline 34 & $\mathrm{H}$ & $\mathrm{CH}_{2} \mathrm{Cl}$ & $\mathrm{OCH}_{3}$ \\
\hline 35 & $\mathrm{H}$ & $\mathrm{CH}_{2} \mathrm{Cl}$ & $\mathrm{Cl}$ \\
\hline
\end{tabular}


Table 1. Cont.

\begin{tabular}{cccc}
\hline Compound & $\mathbf{R}$ & $\mathbf{R}^{\mathbf{1}}$ & $\mathbf{R}^{\mathbf{2}}$ \\
\hline $\mathbf{3 6}$ & $\mathrm{H}$ & $\mathrm{CH}_{2} \mathrm{Cl}$ & $\mathrm{Br}$ \\
$\mathbf{3 7}$ & $\mathrm{H}$ & $\mathrm{CH}_{2} \mathrm{Cl}$ & $\mathrm{F}$ \\
$\mathbf{3 8}$ & $\mathrm{H}$ & $\mathrm{CH}_{2} \mathrm{Cl}$ & $\mathrm{NO}_{2}$ \\
$\mathbf{3 9}$ & $\mathrm{H}$ & $\mathrm{CH}_{2} \mathrm{Cl}$ & $\mathrm{CN}$ \\
$\mathbf{4 0}$ & $\mathrm{H}$ & $\mathrm{COOH}$ & $\mathrm{H}$ \\
$\mathbf{4 1}$ & $\mathrm{H}$ & $\mathrm{COOH}$ & $\mathrm{CH}_{3}$ \\
$\mathbf{4 2}$ & $\mathrm{H}$ & $\mathrm{COOH}$ & $\mathrm{OCH}_{3}$ \\
$\mathbf{4 3}$ & $\mathrm{H}$ & $\mathrm{COOH}$ & $\mathrm{Cl}$ \\
$\mathbf{4 4}$ & $\mathrm{H}$ & $\mathrm{COOH}$ & $\mathrm{Br}$ \\
$\mathbf{4 5}$ & $\mathrm{H}$ & $\mathrm{COOH}$ & $\mathrm{F}$ \\
$\mathbf{4 6}$ & $\mathrm{H}$ & $\mathrm{COOH}$ & $\mathrm{NO}_{2}$ \\
$\mathbf{4 7}$ & $\mathrm{CH}$ & $\mathrm{CH} 2 \mathrm{OH}$ & $\mathrm{H}$ \\
$\mathbf{4 8}$ & $\mathrm{CH}_{3}$ & $\mathrm{CH}_{2} \mathrm{OH}$ & $\mathrm{CH}_{3}$ \\
$\mathbf{4 9}$ & $\mathrm{CH}_{3}$ & $\mathrm{CH}_{2} \mathrm{OH}$ & $\mathrm{Cl}$ \\
$\mathbf{5 0}$ & $\mathrm{CH}_{3}$ & $\mathrm{CH}_{2} \mathrm{OH}$ & $\mathrm{Br}^{2}$ \\
$\mathbf{5 1}$ & $\mathrm{CH}_{3}$ & $\mathrm{CH}_{2} \mathrm{OH}$ & $\mathrm{F}$ \\
$\mathbf{5 2}$ & $\mathrm{CH}_{3}$ & $\mathrm{CH}_{2} \mathrm{OH}$ & $\mathrm{OCH}_{3}$ \\
$\mathbf{5 3}$ & $\mathrm{CH}_{3}$ & $\mathrm{CH}_{2} \mathrm{OH}$ & $\mathrm{NO}_{2}$ \\
\hline
\end{tabular}

\section{Results and Discussion}

\subsection{Chemistry}

Our target molecules were based on benzimidazole derivatives. It is possible to design a wide range of potential microbial inhibitors by replacing the hydrogen at various positions of the benzimidazole ring with different functional groups. However, the most accessible derivatives are those with substituents at the 1-, 2- and 5-positions. Retrosynthetic analysis of a 2,5-disubstituted benzimidazole identified two fragments, which explains why these particular substituted benzimidazoles are easy to prepare (Figure 1). The reactions of substituted 1,2-phenylenediamines and carboxylic acids can provide access to a library of compounds. In this application, the design of these inhibitors focused on 5-substituted benzimidazoles followed by the synthesis of 2,5-disubstituted analogues based on (1H-benzimidazole-2-yl)methanol derivatives, $(1 H$-benzimidazole-2-yl)alkylamines derivatives, $(1 H$-benzimidazole-2-yl)-ethyl derivatives and (1H-benzimidazole-2-yl)-methanethiol derivatives (Scheme 1). The general method for the synthesis of these benzimidazoles 1-31 was based on the Phillips procedure [27].

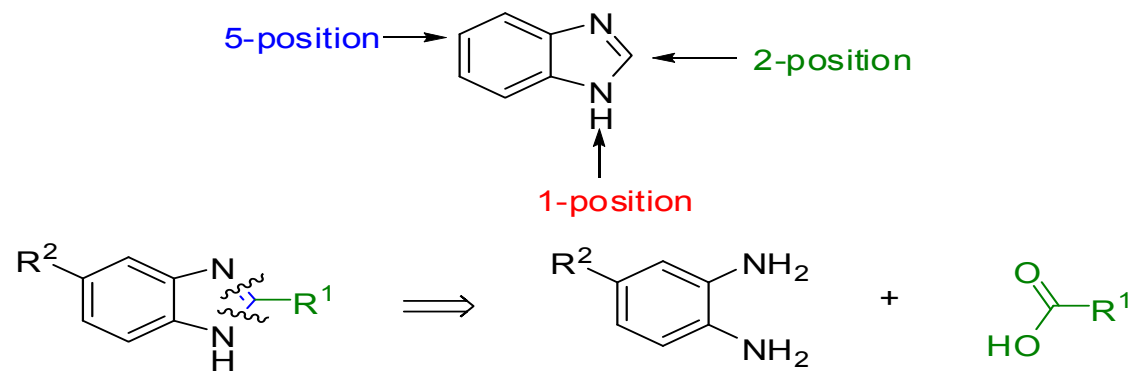

Figure 1. Retrosynthetic analysis of benzimidazole. 


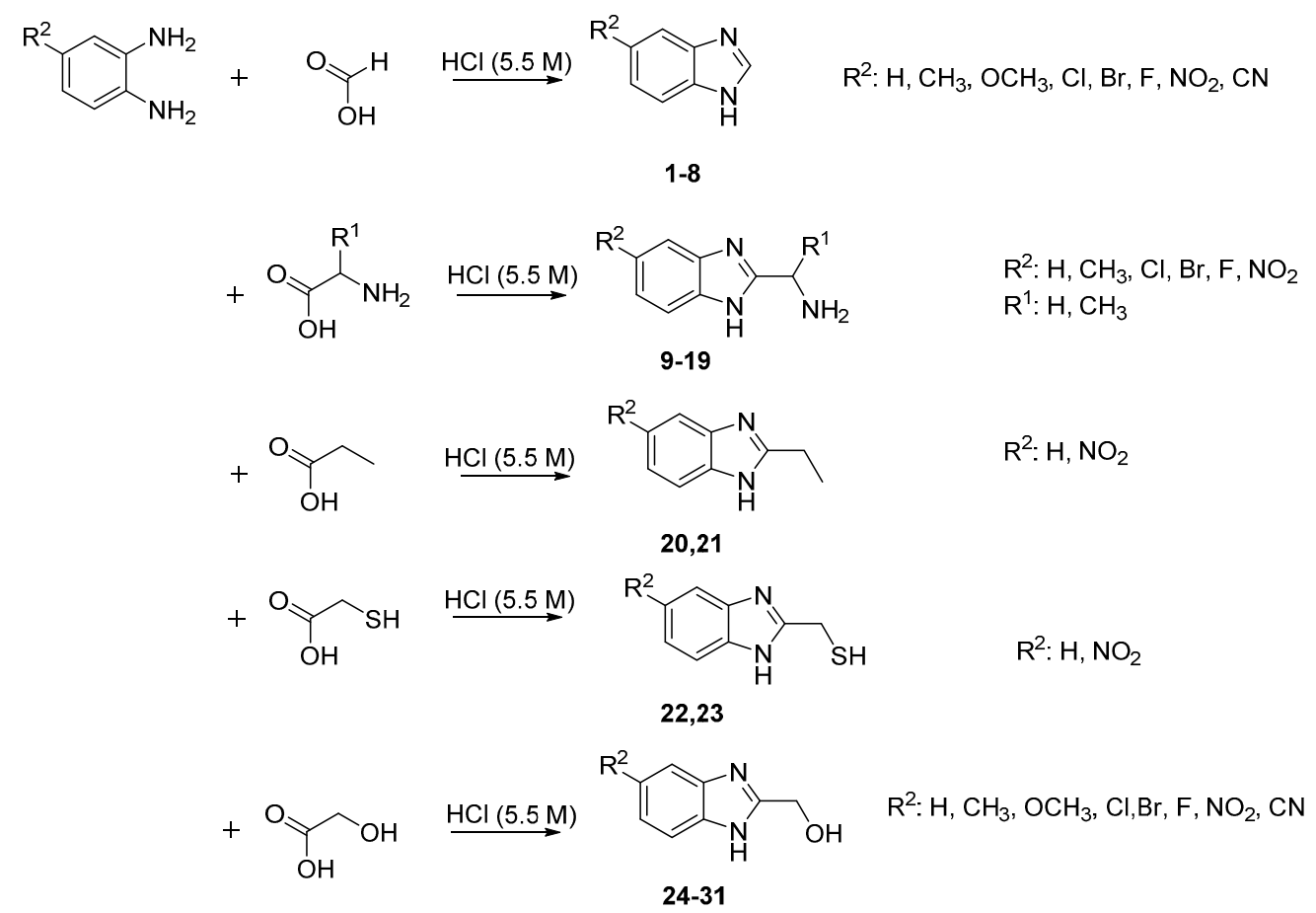

Scheme 1. 2,5-Substituted benzimidazole derivatives.

The $1 H$-benzimidazole-2-yl)methanol derivatives were readily reacted further (oxidation, chlorination and $N$-alkylation) (Scheme 2). The hydroxyl group of (1H-benzimidazole-2-yl)methanol was converted into the chloromethyl through a reaction with thionyl chloride to give 2-(chloromethyl)- $1 H$-benzimidazole Derivatives 32-39. The 2-chloromethylbenzimidazoless were required for the biological studies to provide a direct comparison with other functional groups in the 2-position of benzimidazole [28]. Benzimidazole2-carboxylic Acids 40-46 were readily obtained through simple oxidation of ( $1 H$-benzimidazole-2-yl)methanol Derivatives 24-30 using potassium permanganate. The $N$-methylation of Derivatives 24-30 gave the corresponding $N$-methyl-5-substituted (1H-benzimidazole-2-yl)methanol derivatives 47-53.<smiles>[R]c1ccc2[nH]c(CO)nc2c1</smiles>

24-31

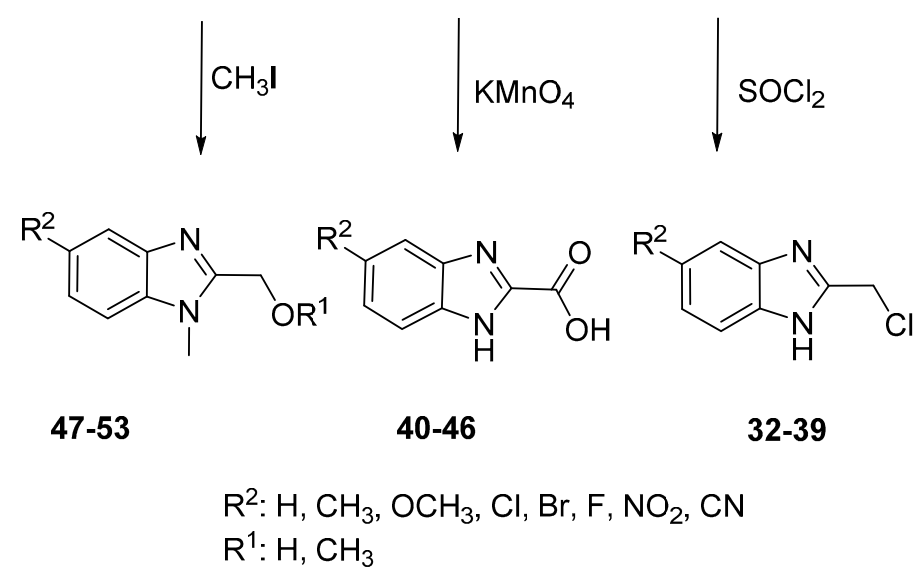

Scheme 2. Conversion of 2-methanol benzimidazole derivatives. 


\subsection{Biological Evaluation}

\subsubsection{Antibacterial Activity}

Firstly, a cut-off point of an inhibition zone diameter of $\geq 12 \mathrm{~mm}$ was used to define appreciable antibacterial activity. Using this criteria, disc diffusion tests with the 53 compounds revealed that nine compounds $(9,17,18,22,32,33,35,36$ and 52) had some degree of antibacterial activity (Table 2); with five exhibiting activity against representatives of at least two Staphylococcal species. Six compounds had activity against one or more strains of Methicillin-resistant Staphylococcus aureus (MRSA), including strains that were resistant to ciprofloxacin. Six compounds had some activity against S. epidermidis and three against the single strain of $S$. haemolyticus used in this study. Regarding the Gram-negative bacteria, only two (32 and 52) of the compounds tested were active against any of the five strains of Escherichia coli and none against the four strains of Pseudomonas aeruginosa. Two compounds were active against the single strain of Serratia marcescens, but six had some activity against the single strain of B. cepacia used in the screening panel. Compounds 17, 18, 22, 35 and 36 were the most active compounds overall, and these were selected on the basis of a broad spectrum of activity, and/or wide zones of inhibition, or novel chemical structure. As summarised in Table 2, these five compounds were investigated further in minimum inhibitory concentration (MIC) assays to quantify their activity against the reference isolates. Testing confirmed that they exhibited little activity against the Gram-negative species, with the exception of Burkholderia cepacia. However, for the Gram-positive species, there were some MICs as low as 64 and even $32 \mu \mathrm{g} / \mathrm{mL}$. Notably, Compounds $\mathbf{1 7}$ and $\mathbf{1 8}$ had MICs comparable to that of ciprofloxacin against two of the MRSA strains, whilst 22 and $\mathbf{3 6}$ had consistent activity (MIC 32-64 $\mu \mathrm{g} / \mathrm{mL}$ ) against almost all of the staphylococci. This is significant and provides lead compounds for further development.

Table 2. Antibacterial activity of selected benzimidazole derivatives against Gram-positive and Gram-negative bacteria (series of 2-ethanamine, 2-methanthiol, 2-chlromethyl and $N$-methyl benzimidazole derivatives).

\begin{tabular}{|c|c|c|c|c|c|c|c|c|c|c|}
\hline \multirow[t]{2}{*}{ Bacterial Species Compound } & \multicolumn{10}{|c|}{$\begin{array}{l}\text { Diameter of the Inhibition Zone (mm) around } \\
\text { Each Compound in the Agar Diffusion Test }\end{array}$} \\
\hline & 9 & 17 & 18 & 22 & 32 & 33 & 35 & 36 & 52 & Ciprofloxacin \\
\hline \multicolumn{11}{|l|}{ Gram-Positive } \\
\hline Staphylococcus aureus NCTC 6571 & 0 & 10 & 11 & 11 & 13 & 9 & 9 & 9 & 14 & 27 \\
\hline Staphylococcus aureus NCTC 10399 & 0 & 12 & 12 & 16 & 7 & 7 & 0 & 0 & 17 & 33 \\
\hline MRSA HG-1 & 0 & 10 & 11 & 12 & 0 & 0 & 0 & 13 & 13 & 0 \\
\hline MRSA-15 NCTC 13142 & 0 & 11 & 10 & 12 & 0 & 0 & 9 & 14 & 15 & 28 \\
\hline MRSA-16 NCTC 13143 & 0 & 10 & 13 & 15 & 0 & 0 & 10 & 15 & 13 & 0 \\
\hline MRSA BIG 0043 & 0 & 11 & 10 & 11 & 9 & 10 & 9 & 11 & 12 & 0 \\
\hline MRSA BIG 0044 & 0 & 9 & 12 & 12 & 10 & 10 & 9 & 15 & 12 & 0 \\
\hline MRSA BIG 0045 & 0 & 11 & 11 & 14 & 0 & 12 & 9 & 11 & 13 & 0 \\
\hline MRSA BIG 0047 & 0 & 12 & 13 & 12 & 0 & 11 & 9 & 11 & 13 & 0 \\
\hline MRSA BIG 0050 & 0 & 0 & 12 & 11 & 0 & 9 & 9 & 15 & 13 & 0 \\
\hline MRSA BIG 0052 & 0 & 0 & 13 & 11 & 0 & 9 & 9 & 14 & 12 & 0 \\
\hline MRSA BIG 0053 & 0 & 0 & 11 & 13 & 0 & 10 & 9 & 14 & 13 & 0 \\
\hline Staphylococcus epidermidis NCTC 11047 & 0 & 0 & 11 & 0 & 10 & 12 & 0 & 0 & 12 & 32 \\
\hline Staphylococcus epidermidis NCTC 2749 & 17 & 9 & 13 & 13 & 9 & 10 & 14 & 9 & 13 & 35 \\
\hline Staphylococcus haemolyticus NCTC 11042 & 0 & 12 & 10 & 18 & 11 & 11 & 0 & 0 & 15 & 34 \\
\hline
\end{tabular}


Table 2. Cont.

\begin{tabular}{|c|c|c|c|c|c|c|c|c|c|c|}
\hline \multirow[t]{2}{*}{ Bacterial Species Compound } & \multicolumn{10}{|c|}{$\begin{array}{l}\text { Diameter of the Inhibition Zone (mm) around } \\
\text { Each Compound in the Agar Diffusion Test }\end{array}$} \\
\hline & 9 & 17 & 18 & 22 & 32 & 33 & 35 & 36 & 52 & Ciprofloxacin \\
\hline \multicolumn{11}{|l|}{ Gram-Negative } \\
\hline Burkholderia cepacia NCTC 10744 & 12 & 11 & 10 & 15 & 0 & 12 & 15 & 17 & 12 & 27 \\
\hline Escherichia coli NCTC 10418 & 0 & 0 & 0 & 0 & 13 & 9 & 9 & 9 & 14 & 33 \\
\hline Escherichia coli $\mathrm{BIG} 0046$ & 0 & 0 & 0 & 0 & 9 & 9 & 8 & 0 & 9 & 0 \\
\hline Escherichia coli BIG 0048 & 0 & 0 & 0 & 0 & 15 & 9 & 8 & 8 & 11 & 0 \\
\hline Escherichia coli BIG 0049 & 0 & 0 & 0 & 0 & 11 & 0 & 7 & 8 & 8 & 0 \\
\hline Escherichia coli 0051 & 0 & 0 & 0 & 0 & 12 & 9 & 7 & 0 & 10 & 0 \\
\hline Pseudomonas aeruginosa NCTC 6749 & 0 & 0 & 0 & 0 & 10 & 0 & 0 & 0 & 10 & 33 \\
\hline Pseudomonas aeruginosa BIG 0039 & 0 & 0 & 0 & 0 & 0 & 0 & 0 & 0 & 8 & 34 \\
\hline Pseudomonas aeruginosa NCTC 10662 & 0 & 0 & 0 & 0 & 10 & 0 & 0 & 0 & 8 & 32 \\
\hline Pseudomonas aeruginosa BIG 0063 & 0 & 0 & 0 & 0 & 10 & 0 & 0 & 0 & 9 & 30 \\
\hline Serratia marcescens NCTC 1377 & 0 & 0 & 0 & 0 & 15 & 8 & 9 & 8 & 13 & 32 \\
\hline
\end{tabular}

Zone diameters indicative of antibacterial activity (i.e., $\geq 12 \mathrm{~mm}$ ) are highlighted in bold.

Interestingly, the MICs of Compounds 17 and 18 (2-ethanamine benzimidazole derivatives) against the investigated bacteria were similar to each other (Table 3 ). This suggests that the higher electronegativity of bromine and chlorine increased the antibacterial activity, and this was also observed by Tavman [29].

Table 3. MICs of the selected benzimidazole derivatives against the reference panel of Gram positive and Gram negative bacteria.

\begin{tabular}{lcccccc}
\hline \multirow{2}{*}{ Bacterial Strain } & \multicolumn{5}{c}{ MIC $(\boldsymbol{\mu g} / \mathbf{m L})$ per Compound } \\
\cline { 2 - 7 } & $\mathbf{1 7}$ & $\mathbf{1 8}$ & $\mathbf{2 2}$ & $\mathbf{3 5}$ & $\mathbf{3 6}$ & Ciprofloxacin \\
\hline Gram-Positive & & & & & & \\
\hline Staphylococcus aureus NCTC 6571 & $\mathbf{3 2}$ & $\mathbf{3 2}$ & 64 & 128 & 64 & $\leq 0.5$ \\
Staphylococcus aureus NCTC 10399 & 256 & 256 & 64 & 128 & 64 & $>32$ \\
MRSA HG-1 & $\mathbf{3 2}$ & $\mathbf{3 2}$ & 64 & 265 & 64 & $\mathbf{3 2}$ \\
MRSA-15 NCTC 13142 & 256 & 256 & 64 & 128 & 64 & $\leq 0.5$ \\
MRSA-16 NCTC 13143 & 256 & 256 & 64 & 256 & 64 & 32 \\
MRSA BIG 0043 & 256 & 256 & 64 & 256 & 64 & $>32$ \\
MRSA BIG 0044 & $>512$ & $>512$ & 64 & 256 & 64 & $>32$ \\
MRSA BIG 0045 & 256 & 256 & 64 & 256 & $>512$ & 8 \\
MRSA BIG 0047 & 256 & 256 & 64 & 256 & 64 & 8 \\
MRSA BIG 0050 & $\mathbf{3 2}$ & $\mathbf{3 2}$ & 64 & 256 & 64 & $\mathbf{3 2}$ \\
MRSA BIG 0052 & 256 & 256 & 64 & 256 & 64 & $\leq 0.5$ \\
MRSA BIG 0053 & 256 & 256 & 64 & 256 & 64 & $>32$ \\
Staphylococcus epidermidis NCTC 11047 & 256 & 256 & 32 & 256 & 32 & $\leq 0.5$ \\
Staphylococcus epidermidis NCTC 2749 & 256 & 256 & 64 & 256 & 64 & $\leq 0.5$ \\
Staphylococcus haemolyticus NCTC 11042 & 256 & 265 & 32 & 256 & 32 & 8 \\
\hline
\end{tabular}


Table 3. Cont.

\begin{tabular}{lcccccc}
\hline \multirow{2}{*}{\multicolumn{1}{c}{ Bacterial Strain }} & \multicolumn{5}{c}{ MIC $(\boldsymbol{\mu g} / \mathbf{m L})$ per Compound } \\
\cline { 2 - 7 } & $\mathbf{1 7}$ & $\mathbf{1 8}$ & $\mathbf{2 2}$ & $\mathbf{3 5}$ & $\mathbf{3 6}$ & Ciprofloxacin \\
\hline Gram-Negative & & & & & & \\
\hline Burkholderia cepacia NCTC 10744 & 32 & 32 & 64 & 256 & 64 & $\leq 0.5$ \\
Escherichia coli NCTC 10418 & $>512$ & $>512$ & 512 & $>512$ & $>512$ & $\leq 0.5$ \\
Escherichia coli BIG 0046 & $>512$ & $>512$ & $>512$ & $>512$ & $>512$ & 32 \\
Escherichia coli BIG 0048 & $>512$ & $>512$ & 512 & $>512$ & $>512$ & 8 \\
Escherichia coli BIG 0049 & $>512$ & $>512$ & $>512$ & $>512$ & $>512$ & 8 \\
Escherichia coli BIG 0051 & $>512$ & $>512$ & $>512$ & $>512$ & $>512$ & 32 \\
Pseudomonas aeruginosa NCTC 6749 & $>512$ & $>512$ & $>512$ & 512 & 265 & $\leq 0.5$ \\
Pseudomonas aeruginosa BIG 0039 & $>512$ & $>512$ & $>512$ & 512 & 512 & $\leq 0.5$ \\
Pseudomonas aeruginosa NCTC 10662 & $>512$ & $>512$ & $>512$ & 512 & 512 & $\leq 0.5$ \\
Pseudomonas aeruginosa BIG 0063 & $>512$ & $>512$ & $>512$ & 512 & 512 & $\leq 0.5$ \\
Serratia marcescens NCTC 1377 & $>512$ & $>512$ & $>512$ & $>512$ & $>512$ & $\leq 0.5$ \\
\hline
\end{tabular}

Good activity, relative to the MIC of ciprofloxacin, is indicated in bold. The results are the average of three independent readings.

For the 2-methanthiol benzimidazole derivatives (22-23, Scheme 1), the unsubstituted derivative at position 5, Compound 22, was selectively active against all of the Gram-positive bacteria with an MIC of $32 \mu \mathrm{g} / \mathrm{mL}$ against $S$. epidermidis NCTC 11047 and S. haemolyticus NCTC 11042 and MIC $64 \mu \mathrm{g} / \mathrm{m}$ against the other staphylococci plus B. cepacia (Table 3). The inhibitory activity decreases when position 5 is methylated as in Compound 23 ( $>512 \mathrm{MIC} \mu \mathrm{g} / \mathrm{mL}$ ). This was also observed by Podunavac-Kuzmanovic and Cvetkovic [30], who found that the unsubstituted analogue was more potent than the methyl analogues of the 2-aminobenzimidazole against strains of Bacillus cereus, Staphylococcus aureus, Sarcina lutea and Pseudomonas aeruginosa.

From the series of 2-chloromethyl benzimidazole derivatives (Scheme 2), 36 (5-Br) was the most active compound with inhibition zone diameters of 13-17 $\mathrm{mm}$. The largest zones of inhibition $(17 \mathrm{~mm}$ and $15 \mathrm{~mm}$ diameter) were exhibited by Compounds $35(5-\mathrm{Cl})$ and 36, respectively, against Burkholderia cepacia NCTC 10744. Only 35 and 36 were capable of inhibiting some strains at a concentration below $256 \mu \mathrm{g} / \mathrm{mL}$. As shown in Table 3, Compound 36, the brominated derivative, was more active than Compound 35, which is the chlorinated derivative. This could support the hypothesis that there is a direct relationship between biological activity and the electron withdrawing effect [29].

\subsubsection{Antifungal Activity}

The well diffusion tests of the 53 compounds against the fungi revealed very interesting results: 21 compounds were active against Aspergillus clavatus RCMB 2593; 28 had some activity against Aspergillus fumigatus RCMB 02564; 26 compounds were active against Penicillium marneffei RCMB 01267; 22 compounds were active against Mucor circinelloides RCMB 07328; 20 compounds were active against Absidia corymbifera RCMB 09635; 20 compounds were active against Syncephalastrum racemosum RCMB 05922; 29 compounds were active against Candida albicans RCMB 05035; 29 compounds were active against Candida tropicalis RCMB 05049; 27 compounds were active against Candida parapsilosis RCMB 05065; 13 compounds had some activity against Candida krusei RCMB 05051; 14 compounds had no detectable antifungal activity. 
Amphotericin B was used as a positive control for the antifungal testing. The intention was not to compare activity on a molar basis, since such a comparison does not necessarily have biological validity when comparing compounds with very different modes of action or solubility in diffusion assays. This allowed us to identify the compounds with the most promising activity, which could be looked at in more detail in further studies.

Tables 4 and 5 summarise the results for the 23 compounds that were most active against the fungal strains used. The antifungal screening of the series of 2-ethanamine benzimidazole Derivatives 9-19 showed remarkable antifungal activities against both unicellular and filamentous fungi (Table 4). However, Compound 5 (5-Br) showed the highest antifungal activity; with a 29-mm zone of inhibition against Candida parapsilosis RCMB 05065 and $26 \mathrm{~mm}$ against Candida albicans RCMB 05035, Candida tropicalis RCMB 05049 and Aspergillus fumigatus RCMB 02564 (Table 4). Seven compounds, 2-6, 14 and 20, from the series of 5-substituted benzimidazole derivatives also showed promising antifungal activity (Table 4).

Interestingly, all of the selected 23 compounds showed antifungal activity against both the unicellular and filamentous fungi (Table 4). Moreover, the minimum inhibitory concentration (MIC) of some compounds, against certain fungal species, was better (i.e., lower) than that of the reference drug (Table 5). This suggests that when there is no substituent at position 2 and an electron withdrawing substituent at position 5, the antifungal activity is increased (Tables 4 and 5). This confirms the hypothesis that there is a direct relationship between the antifungal activity and the electron withdrawing effect of substituents. Compound 5 (5-Br) was active against the selected strains with MIC equivalent to half that exhibited by amphotericin B [31].

The antifungal screening of the series of 2-alkylamine benzimidazole derivatives (9-19, Scheme 1) showed interesting antifungal activity for the compounds. Significant activity was observed for Compounds $11(5-\mathrm{Cl})$ and $14\left(5-\mathrm{NO}_{2}\right)$, especially against Mucor circinelloides RCMB 07328 with low MICs of 3.9 and $0.49 \mu \mathrm{g} / \mathrm{mL}$, respectively. However, no activity was observed for the 5-bromo analogue 12. Both Compounds $\mathbf{1 1}$ and $\mathbf{1 4}$ showed remarkable antifungal activity that was almost similar to the reference drug, and interestingly, Compound $\mathbf{1 4}$ was three-fold as potent as the amphotericin B against Mucor circinelloides RCMB 07328. This suggests that the more electrons withdrawing the substituent there are, the higher the antifungal activity (Table 5). Furthermore, Compounds 11 (5-Cl), 13 (5-F), 14 $\left(5-\mathrm{NO}_{2}\right)$ and $15(5-\mathrm{H})$ showed good activity against Candida parapsilosis RCMB 05065; with a MIC range of $1.95-0.06 \mu \mathrm{g} / \mathrm{mL}$, which is for Compounds 11 and 15 equivalent to the MIC of amphotericin B. Compound 13, the 5-fluoro analogue, was three-times more potent, while $14\left(5-\mathrm{NO}_{2}\right)$ was five-fold more potent than the control drug against Candida parapsilosis RCMB 05065. This suggests that when the electron withdrawing effect increases, the antifungal effect also increases.

Compound 27 (5-Br), from the series of 2-methanol benzimidazole derivatives (Scheme 2), exhibited promising antifungal activity against Absidia corymbifera RCMB 09635, Syncephalastrum racemosum RCMB 05922 and Candida krusei RCMB 05051 with MICs equivalent to the reference, and two-fold the latter's potency against Candida parapsilosis RCMB 05065. This suggests that the more electronegative bromine increases the antifungal activity (Table 5) [29]. 
Table 4. Antifungal activity of the benzimidazole derivatives against unicellular and filamentous fungi in the well diffusion assay.

\begin{tabular}{|c|c|c|c|c|c|c|c|c|c|c|c|c|c|c|c|c|c|c|c|c|c|c|c|c|}
\hline \multirow{2}{*}{ Fungal Strain } & \multicolumn{24}{|c|}{ Diameter of Zone of Inhibition $(\mathrm{mm})$ around Each Compound } \\
\hline & 2 & 3 & 4 & 5 & 6 & 7 & 11 & 13 & 14 & 15 & 20 & 22 & 27 & 28 & 33 & 37 & 38 & 42 & 43 & 44 & 51 & 52 & 53 & Am. B \\
\hline \multicolumn{25}{|l|}{ Unicellular } \\
\hline $\begin{array}{l}\text { Candida albicans } \\
\text { RCMB } 05035\end{array}$ & 21 & 21 & 24 & 26 & 23 & 21 & 21 & 20 & 22 & 19 & 23 & 17 & 20 & 18 & 19 & 17 & 22 & 17 & 19 & 20 & 19 & 21 & 22 & 22 \\
\hline $\begin{array}{l}\text { Candida krusei } \\
\text { RCMB } 05051\end{array}$ & 17 & 16 & 19 & 19 & 18 & 14 & 14 & 12 & 17 & 14 & 20 & 17 & 19 & 0 & 0 & 0 & 18 & 0 & 0 & 0 & 0 & 21 & 22 & 19 \\
\hline $\begin{array}{l}\text { Candida parapsilosis } \\
\mathrm{RCMB} 05065\end{array}$ & 21 & 21 & 25 & 29 & 23 & 19 & 19 & 22 & 24 & 19 & 20 & 15 & 21 & 19 & 21 & 18 & 22 & 18 & 16 & 20 & 16 & 18 & 18 & 18 \\
\hline $\begin{array}{l}\text { Candida tropicalis } \\
\text { RCMB } 05049\end{array}$ & 22 & 22 & 25 & 26 & 25 & 21 & 20 & 22 & 22 & 19 & 21 & 15 & 21 & 19 & 20 & 18 & 22 & 18 & 20 & 19 & 20 & 22 & 24 & 25 \\
\hline \multicolumn{25}{|l|}{ Filamentous } \\
\hline $\begin{array}{l}\text { Absidia corymbifera } \\
\text { RCMB } 09635\end{array}$ & 21 & 21 & 22 & 25 & 23 & 15 & 14 & 19 & 21 & 14 & 0 & 0 & 19 & 19 & 19 & 17 & 20 & 16 & 18 & 18 & 20 & 0 & 0 & 20 \\
\hline $\begin{array}{l}\text { Aspergillus clavatus } \\
\text { RCMB } 02593\end{array}$ & 20 & 21 & 23 & 23 & 23 & 17 & 19 & 19 & 21 & 17 & 23 & 19 & 18 & 14 & 15 & 15 & 20 & 14 & 16 & 15 & 18 & 22 & 23 & 22 \\
\hline $\begin{array}{l}\text { Aspergillus fumigatus } \\
\text { RCMB } 02564\end{array}$ & 22 & 21 & 24 & 26 & 23 & 19 & 19 & 20 & 23 & 19 & 23 & 18 & 17 & 16 & 17 & 14 & 20 & 16 & 17 & 17 & 18 & 20 & 21 & 24 \\
\hline $\begin{array}{l}\text { Mucor circinelloides } \\
\text { RCMB } 07328\end{array}$ & 20 & 21 & 21 & 23 & 21 & 17 & 18 & 17 & 21 & 17 & 24 & 19 & 15 & 17 & 18 & 14 & 18 & 12 & 14 & 14 & 20 & 23 & 25 & 18 \\
\hline $\begin{array}{l}\text { Penicillium marneffei } \\
\text { RCMB } 01267\end{array}$ & 19 & 19 & 22 & 25 & 23 & 17 & 16 & 13 & 19 & 15 & 21 & 16 & 17 & 18 & 17 & 18 & 20 & 15 & 16 & 17 & 19 & 21 & 22 & 21 \\
\hline $\begin{array}{l}\text { Syncephalastrum racemosum } \\
\text { RCMB } 05922\end{array}$ & 19 & 19 & 20 & 20 & 19 & 13 & 18 & 18 & 19 & 17 & 24 & 21 & 20 & 0 & 0 & 0 & 19 & 0 & 0 & 0 & $\mathbf{0}$ & 23 & 24 & 20 \\
\hline
\end{tabular}

Good activity, relative to the diameter of the zone of inhibition obtained with amphotericin B (i.e., a diameter $\geq$ amphotericin B (Am. B)), is indicated in bold. 
Table 5. MICs of the tested compounds against unicellular and filamentous fungi.

\begin{tabular}{|c|c|c|c|c|c|c|c|c|c|c|c|c|c|c|c|c|c|c|c|c|c|c|c|c|}
\hline \multirow{2}{*}{ Fungal Strain } & \multicolumn{24}{|c|}{ MIC $(\mu \mathrm{g} / \mathrm{mL})$ per Compound } \\
\hline & 2 & 3 & 4 & 5 & 6 & 7 & 11 & 13 & 14 & 15 & 20 & 22 & 27 & 28 & 33 & 37 & 38 & 42 & 43 & 44 & 51 & 52 & 53 & Am. B \\
\hline \multicolumn{25}{|l|}{ Unicellular } \\
\hline $\begin{array}{l}\text { Candida albicans } \\
\text { RCMB } 05035\end{array}$ & 0.49 & 0.98 & 0.03 & 0.007 & $\mathbf{0 . 0 3}$ & 0.49 & 0.49 & 0.49 & 0.24 & 1.95 & 0.24 & 31.3 & 0.98 & 3.9 & 1.95 & 7.8 & 0.24 & 7.8 & 0.98 & 0.98 & 0.98 & 0.98 & 0.98 & 0.12 \\
\hline $\begin{array}{l}\text { Candida krusei } \\
\text { RCMB } 05051\end{array}$ & 7.8 & 15.6 & 1.95 & 0.98 & 0.98 & 31.25 & 62.5 & 31.3 & 7.8 & 62.5 & 1.95 & 15.6 & 0.98 & $>500$ & $>500$ & $>500$ & 1.95 & $>500$ & $>500$ & $>500$ & $>500$ & 0.98 & 0.94 & 0.98 \\
\hline $\begin{array}{l}\text { Candida parapsilosis } \\
\text { RCMB } 05065\end{array}$ & 0.24 & 0.12 & 0.03 & 0.003 & 0.06 & 0.98 & 1.95 & 0.24 & 0.06 & 1.95 & 1.95 & 125 & 0.49 & 1.95 & 0.24 & 1.95 & 0.12 & 1.95 & 0.98 & 0.98 & 15.6 & 7.8 & 7.8 & 1.95 \\
\hline $\begin{array}{l}\text { Candida tropicalis } \\
\text { RCMB } 05049\end{array}$ & 0.24 & 0.24 & 0.02 & 0.007 & 0.06 & 0.49 & 0.98 & 0.24 & 0.12 & 0.98 & 1.95 & 62.5 & 0.49 & 1.95 & 0.49 & 3.9 & 0.12 & 3.9 & 1.95 & 1.95 & 0.49 & 0.49 & 0.12 & 0.02 \\
\hline \multicolumn{25}{|l|}{ Filamentous } \\
\hline $\begin{array}{l}\text { Absidia corymbifera } \\
\text { RCMB } 09635\end{array}$ & 0.24 & 0.24 & 0.12 & 0.03 & 0.06 & 15.63 & 31.3 & 1.95 & 0.49 & 62.5 & $>500$ & $>500$ & 0.98 & 3.9 & 1.95 & 7.8 & 0.98 & 7.8 & 7.8 & 3.9 & 0.98 & $>500$ & $>500$ & 0.98 \\
\hline $\begin{array}{l}\text { Aspergillus clavatus } \\
\text { RCMB } 02593\end{array}$ & 0.49 & 0.98 & 0.12 & 0.06 & 0.12 & 3.9 & 1.95 & 1.95 & 0.24 & 3.9 & 0.24 & 3.9 & 1.95 & 62.5 & 31.3 & 31.3 & 0.98 & 62.5 & 15.6 & 31.3 & 3.9 & 0.49 & 0.24 & 0.12 \\
\hline $\begin{array}{l}\text { Aspergillus fumigatus } \\
\text { RCMB } 02564\end{array}$ & 0.24 & 0.24 & 0.06 & 0.02 & 0.06 & 1.95 & 1.95 & 0.98 & 0.12 & 1.95 & 0.49 & 7.8 & 3.9 & 15.6 & 7.8 & 62.5 & 0.49 & 15.6 & 7.8 & 7.8 & 1.95 & 1.95 & 0.98 & 0.06 \\
\hline $\begin{array}{l}\text { Mucor circinelloides } \\
\text { RCMB } 07328\end{array}$ & 0.49 & 0.49 & 0.24 & 0.12 & 0.12 & 7.8 & 3.9 & 7.8 & 0.49 & 15.6 & 0.12 & 1.95 & 31.3 & 7.8 & 1.95 & 62.5 & 1.95 & 125 & 62.5 & 62.5 & 0.98 & 0.24 & 0.12 & 3.9 \\
\hline $\begin{array}{l}\text { Penicillium marneffei } \\
\text { RCMB } 01267\end{array}$ & 1.95 & 0.98 & 0.12 & 0.03 & $\mathbf{0 . 0 3}$ & 7.8 & 15.6 & 62.5 & 0.98 & 15.6 & 1.95 & 31.3 & 3.9 & 1.95 & 3.9 & 1.95 & 0.98 & 15.6 & 15.6 & 7.8 & 1.95 & 0.98 & 0.49 & 0.49 \\
\hline Syncephalastrum & & & & & & & & & & & & & & & & & & & & & & & & \\
\hline $\begin{array}{l}\text { racemosum } \\
\mathrm{RCMB} 05922\end{array}$ & 1.95 & 1.95 & 0.98 & 0.98 & 0.98 & 125 & 3.9 & 3.9 & 0.98 & 3.9 & 0.24 & 0.98 & 0.98 & $>500$ & $>500$ & $>500$ & 1.95 & $>500$ & $>500$ & $>500$ & $>500$ & 0.24 & 0.12 & 0.98 \\
\hline
\end{tabular}


In the 2-carboxylic acid benzimidazole series (Scheme 2), good antifungal activity was obtained for two compounds, $43(5-\mathrm{Cl})$ and $44(5-\mathrm{Br})$, with a MIC of $0.98 \mu \mathrm{g} / \mathrm{mL}$ only against Candida parapsilosis RCMB 05065, which is twice the potency exhibited by the reference drug. However, when comparing these results to their unsubstituted (at position 2) analogues from series of 5-substituted benzimidazoles $(5,5-\mathrm{Br})$, the latter compounds were more active antifungals. Therefore, this result confirmed that the activity is dependent on the halogen substituents at position 5 (Table 5) [29].

Antifungal activity for two compounds in the 2-chloromethyl benzimidazole series (Scheme 2), 33 (5-Me) and $\mathbf{3 8}\left(5-\mathrm{NO}_{2}\right)$, showed MICs of $1.95 \mu \mathrm{g} / \mathrm{mL}$ against Mucor circinelloides RCMB 07328, which is one-fold as potent as amphotericin B. In addition, the MICs for these compounds were higher than the standard drug by three- to four-fold against Candida parapsilosis RCMB 05065 (Table 5). This could be explained, in the case of $\mathbf{3 8}\left(5-\mathrm{NO}_{2}\right)$, which was more active than the methyl derivative $\mathbf{3 3}$, by the presence of the highly electron withdrawing substituent. As a result, Compound $\mathbf{3 8}\left(5-\mathrm{NO}_{2}\right)$ is almost two times as active as Compound $\mathbf{3 3}$ (5-Me) (Table 5).

Compound $20(5-\mathrm{H})$, from the 2-ethylbenzimidazole series (Scheme 1), exhibited good activity against Mucor circinelloides RCMB 07328 (MIC of $0.12 \mu \mathrm{g} / \mathrm{mL}$; five-fold the potency of amphotericin B) and against Syncephalastrum racemosum RCMB 05922 (MIC of $0.24 \mu \mathrm{g} / \mathrm{mL}$; three-fold the potency of amphotericin B) (Table 5). Interestingly, Compound 20, which is unsubstituted at position 5, showed promising activity, while the nitro derivative 21 was inactive (Table 5). Surprisingly, the inhibition activity decreases when the electron withdrawing effect of the substituent at position 5 increases; this is in contrast to previous results [32].

\section{Experimental Section}

\subsection{Chemistry: General Methods}

The melting points (m.p.) were determined using a Gallenkamp melting point apparatus. The IR spectra were recorded in $\mathrm{KBr}$ discs on a Nicolet 140 FTIR spectrophotometer $\left(v_{\max }\right.$ in $\left.\mathrm{cm}^{-1}\right) .{ }^{1} \mathrm{H}-$ and ${ }^{13} \mathrm{C}-\mathrm{NMR}$ spectra were recorded using a Bruker DPX400 spectrometer. Coupling constants are given in Hertz $(\mathrm{Hz})$. Deuterated solvents were obtained from Goss Scientific Instruments. Deuterated chloroform was stored over $4 \AA$ molecular sieves. DMSO- $d_{6}$ and $\mathrm{D}_{2} \mathrm{O}$ were stored in silica gel desiccators. The mass spectra were obtained on electron impact using an AEI MS902 mass spectrometer. Elemental analysis was carried out by the microanalysis service using $2 \mathrm{mg}$ of the sample (MEDAC LTD, Analytical and Chemical Consultancy Services, Surrey, UK). Spectral data (IR, NMR and mass spectra) confirmed the structures of the compounds.

The purity of all of the compounds was established by ${ }^{1} \mathrm{H}$ - and ${ }^{13} \mathrm{C}-\mathrm{NMR}$ spectroscopy. All of the known compounds were identified by comparing their analytical and physicochemical data with previously reported data. The data for the compounds is provided in the Supplementary Information. 


\subsection{Screening for Antibacterial Activity}

\subsubsection{Bacterial Strains Used in This Project}

All reference and clinical strains were obtained from Dr. Anna Snelling, University of Bradford. Overall, 15 strains of Staphylococcus spp. (including $2 \times$ S. aureus, $10 \times$ MRSA, $2 \times$ S. epidermidis and $1 \times S$. haemolyticus), 5 strains of E. coli, 4 strains of Ps. aeruginosa, 1 strain of Serratia marcescens and 1 strain of Burkholderia cepacia were used.

\subsubsection{Screening for Antibacterial Activity by the Disc Diffusion Method}

Disc diffusion assays for antimicrobial susceptibility testing were carried out in-line with the standard method first described by Bauer (1966), to assess if the compounds had any appreciable antibacterial activities. The broad spectrum antibiotic ciprofloxacin was included in these qualitative tests as a comparator and positive control. Bacterial suspensions were prepared from fresh, overnight, agar cultures in sterile distilled water and adjusted to a 0.5 McFarland turbidity standard (Remel, Lenexa, KS, USA). These suspensions were used to seed Iso-sensitest agar (Oxoid, Hampshire, UK) plates evenly using a sterile swab [33].

For test compounds, each was dissolved to $10 \mathrm{mg} / \mathrm{mL}$ in DMSO, and different amounts of each (typically 10, 100 and $200 \mu \mathrm{g}$ ) were loaded from the working stock solution onto 6-mm diameter sterile Whatmann paper discs (Fisher Scientific, Loughborough, UK) and allowed to dry. The loaded discs were placed flat on the surface of the agar lawns. Each test plate was comprised of five discs: three impregnated, one positive control (ciprofloxacin $5 \mu \mathrm{g}$ ) and one negative control (impregnated with $20 \mu \mathrm{L}$ of $100 \%$ DMSO). The plates were incubated at $37^{\circ} \mathrm{C}$ for $24 \mathrm{~h}$. At the end of incubation, the plates were examined for zones of inhibition. Diameters of inhibition zones were measured (in $\mathrm{mm}$ ) and recorded. If any activity was observed, the test was repeated on a separate day, using another fresh culture.

\subsubsection{Determination of Minimum Inhibitory Concentration of Compounds against Bacterial Strains}

For quantitative assessment of activity, the MICs of the synthesised compounds plus ciprofloxacin were determined by the agar dilution method using Iso-sensitest agar. Agar dilution was in the range of $0.5-512 \mu \mathrm{g} / \mathrm{mL}$ of each compound, in doubling dilutions. Iso-sensitest agar was sterilised in $19-\mathrm{mL}$ aliquots, using sufficient base powder for $20 \mathrm{~mL}$. Once it had cooled to approximately $50{ }^{\circ} \mathrm{C}$, an appropriate amount of the test compound was added in a volume of $1 \mathrm{~mL}$, to give the desired final concentration per plate. Bacterial suspensions were prepared as in the previous section.

Strains were seeded $(\sim 10 \mu \mathrm{L})$ on to the freshly-prepared MIC agar plates using a multi-point inoculator (Denley, Guangzhou, China). After briefly allowing the inocula to dry, the plates were incubated overnight at $37^{\circ} \mathrm{C}$ and the MIC was recorded as the lowest concentration of compound that inhibited bacterial growth completely, as indicated by the absence of any visible growth in the inoculation spot on the agar surface. 


\subsection{Screening for Antifungal Activity}

\subsubsection{Fungal Strains Used in This Project}

The strains were obtained from the Regional Center for Mycology and Biotechnology (RCMB), Al-Azhar University, Cairo, Egypt, and this part of the practical work was done there, as well. Reference isolates for the antifungal screening; included representatives of unicellular fungi, namely Candida albicans RCMB 05035, Candida krusei RCMB 05051, Candida parapsilosis RCMB 05065 and Candida tropicalis RCMB 05049, and filamentous fungi, namely Absidia corymbifera RCMB 09635, Aspergillus clavatus RCMB 2593, Aspergillus fumigatus RCMB 02564, Mucor circinelloides RCMB 07328, Mucor circinelloides RCMB 07328, Absidia corymbifera RCMB 09635, Penicillium marneffei RCMB 01267 and Syncephalastrum racemosum RCMB 05922.

\subsubsection{Screening for Antifungal Activity by the Well Diffusion Method}

A qualitative assessment of antifungal activity was determined by the well diffusion method according to the National Committee for Clinical Laboratory Standards (NCCLS) methodology (National Committee for Clinical Laboratory Standards, 1993). Petri dishes containing $20 \mathrm{~mL}$ of malt extract agar (Oxoid) were seeded with 2-3 day old cultures of fungal inoculums (suspensions of spores in sterile water). Wells ( $6 \mathrm{~mm}$ in diameter) were cut into the agar with a sterile cork borer, and $50 \mu \mathrm{L}$ of compound diluted in DMSO were added at a concentration of $5 \mathrm{mg} / \mathrm{mL}\left(250 \mu \mathrm{g}\right.$ per well). Plates were incubated at $37{ }^{\circ} \mathrm{C}$ (unicellular strains) or $28^{\circ} \mathrm{C}$ (filamentous strains) for 3-7 days depending on the growth rate of each strain. Antifungal activity was determined based on the measurement of the diameter of the inhibition zone formed around each well.

\subsubsection{Determination of Minimum Inhibitory Concentration of Compounds against Fungal Strains}

For quantitative assessment of activity, chemical compounds showing activity in the well diffusion tests were diluted in DMSO, and then serial doubling dilutions were made in sterile growth media. The commonly-used antifungal drug amphotericin B (Sigma-Aldrich A9528, St. Louis, MO, USA) was included as a comparator. Dilutions were placed in separate wells of a 96-well microtitre tray (Sarstedt). A volume of standardized inoculum equal to the volume of the diluted compound was added to each well, bringing the microbial concentration to approximately $5 \times 10^{5}$ cells per $\mathrm{mL}$. The trays were incubated at a temperature appropriate for the test species $\left(28^{\circ} \mathrm{C}\right.$ or $\left.37^{\circ} \mathrm{C}\right)$, for a pre-set period $(2-3$ days $)$. After incubation, the series of dilution wells was observed for fungal growth, usually indicated by turbidity and/or a pellet of fungi in the bottom of the well. For each test compound, the lowest concentration that completely inhibited growth was recorded as its minimum inhibitory concentration (MIC).

\section{Conclusions}

A series 53 compounds were synthesized based on the 2-benzimidazole nucleus. While none of the compounds were novel, 47 of them were herein tested against a panel of strains of bacteria and fungi for the first time. Infections caused by MRSA variants of $S$. aureus are particularly difficult to treat, as the strains are resistant to $\beta$-lactams and often manifest resistance to other classes of drug, too, such as the 
fluoroquinolones. Thus, compounds active against the MRSA strains used in this study can be considered promising lead compounds. In terms of the SAR, the key factor in this case is the presence of the chlorine or bromine substituent at position 5 of the benzimidazole ring, and the presence of $\mathrm{CH}\left(\mathrm{CH}_{3}\right) \mathrm{NH}_{2}$ or $\mathrm{CH}_{2} \mathrm{Cl}$ at position 2. Moreover, the presence of $\mathrm{CH}_{2} \mathrm{SH}$ at position 2 ( $\mathrm{H}$ at position 5) proved effective for antimicrobial activity. Derivatives with $\mathrm{CH}_{2} \mathrm{NH}_{2}$ were not active against bacteria, but when a branched methyl group is added $\left(\mathrm{CH}\left(\mathrm{CH}_{3}\right) \mathrm{NH}_{2}\right)$, the antibacterial activity is improved. The latter compounds were prepared from $S$-alanine. Therefore, the product, which is also chiral, showed variable activity against the MRSA species. Chirality is a feature for many drugs, with one of the stereoisomers active biologically and the other inactive or even toxic. Therefore, the chirality has a significant impact on enhancing the biological activity of the compound. However, as in the case of the antifungal assay, and according to the SAR study, an extremely important factor is the nature of the substituent attached to the aromatic ring. The presence of the halogen atom $(\mathrm{Cl}, \mathrm{Br}, \mathrm{F})$ at position 5, increased the antifungal activity. For the 5-nitro derivative, the presence of $\mathrm{CH}_{2} \mathrm{NH}_{2}$ at position 2 increased the activity. The $\mathrm{N}$-methylated-2-methanolbenzimidazole derivatives were more active than the unmethylated analogues, and this is observed when the substituent at position 5 was $\mathrm{F}$, OMe or $\mathrm{NO}_{2}$. To summarise, according to the SAR analysis, it can be concluded that some derivatives of benzimidazole offer significant possibilities for the development of new broad-spectrum antimicrobial agents. Through appropriate modification and fine-tuning of substituents at positions 1, 2 and 5, new microbial inhibitors are possible, although thorough toxicological evaluation will be needed to assess their utility for medicinal use. To summarise, according to the SAR analysis, it can be concluded that some derivatives of benzimidazole offer significant possibilities for the development of new broad-spectrum antimicrobial agents. The structures of our lead compounds are shown in (Figures 2 and 3).<smiles>[R]c1ccc2[nH]c(C(C)N)nc2c1</smiles>

$17 \mathrm{R}^{2}=\mathrm{Cl}$ $18 \mathrm{R}^{2}=\mathrm{Br}$<smiles>[R]c1ccc2[nH]c(CS)nc2c1</smiles>

$22 \mathrm{R}^{2}=\mathrm{H}$<smiles>[R]c1ccc2[nH]c(CCl)nc2c1</smiles>

$35 \mathrm{R}^{2}=\mathrm{Cl}$ $36 \mathrm{R}^{2}=\mathrm{Br}$

Figure 2. Promising antibacterial derivatives.<smiles>[R]c1ccc2[nH]cnc2c1</smiles>

$5 \mathrm{R}^{2}=\mathrm{Br}$<smiles>[R]c1ccc2[nH]c(CN)nc2c1</smiles>

$11 \mathrm{R}^{2}=\mathrm{Cl}$ $13 R^{2}=F$ $14 \mathrm{R}^{2}=\mathrm{NO}_{2}$<smiles>[R]c1ccc2[nH]c(C(C)N)nc2c1</smiles>

$15 R^{2}=H$<smiles>[R]c1ccc2[nH]c(CC)nc2c1</smiles>

$20 \mathrm{R}^{2}=\mathrm{H}$ $38 \mathrm{R}^{2}=\mathrm{NO}_{2}$

Figure 3. Promising antifungal derivatives.

\section{Supplementary Materials}

Supplementary materials can be accessed at: http:/www.mdpi.com/1420-3049/20/08/15206/s1. 


\section{Acknowledgments}

This research project was supported by a grant from the "Research Centre of the Centre for Female Scientific and Medical Colleges”, Deanship of Scientific Research, King Saud University.

\section{Author Contributions}

N.K. and A.M.S. designed and supervised the research; F.A.S.A. performed the research; N.K., A.M.S. and F.A.S.A. wrote the paper; M.E.Z., A.M.A. and A.S.A. assisted with additional tests and data analysis. All authors read and approved the final manuscript.

\section{Conflicts of Interest}

The authors declare no conflict of interest.

\section{References}

1. Franco, B.E.; Martínez, M.A.; Rodríguez, M.S.; Wertheimer, A.I. The determinants of the antibiotic resistance process. Infect. Drug Resist. 2009, 2, 1-11.

2. Barrett, C.T.; Barrett, J.F. Antibacterials: Are the new entries enough to deal with the emerging resistance problems? Curr. Opin. Biotechnol. 2003, 14, 621-626.

3. Cole, S.T. Who will develop new antibacterial agents? Philos. Trans. R. Soc. B Biol. Sci. 2014, 369 , doi:10.1098/rstb.2013.0430.

4. Imperi, F.; Massai, F.; Facchini, M.; Frangipani, E.; Visaggio, D.; Leoni, L.; Bragonzi, A.; Visca, P. Repurposing the antimycotic drug flucytosine for suppression of Pseudomonas aeruginosa pathogenicity. Proc. Natl. Acad. Sci. USA 2013, 110, 7458-7463.

5. Wang, M.; Han, X.; Zhou, Z. New substituted benzimidazole derivatives: A patent review (2013-2014). Expert Opin. Ther. Pat. 2015, 25, 595-612.

6. Soderlind, K.J.; Gorodetsky, B.; Singh, A.K.; Bachur, N.R.; Miller, G.G.; Lown, J.W. Bis-benzimidazole anticancer agents: Targeting human tumour helicases. Anticancer Drug Des. 1999, 14, 19-36.

7. Kumar, K.; Awasthi, D.;Lee, S.Y. ; Cummings, J.E. ; Knudson, S.E. ; Slayden, R.A.; Ojima, I. Benzimidazole-based antibacterial agents against Francisella tularensis. Bioorg. Med. Chem. 2013, 21, 3318-3326.

8. Mentese, E.; Bektas, H.; Ulker, S.; Bekircan, O.; Kahveci, B. Microwave-assisted synthesis of new benzimidazole derivatives with lipase inhibition activity. J. Enzyme Inhib. Med. Chem. 2014, 29, 64-68.

9. Velík, J.; Baliharová, V.; Fink-Gremmels, J.; Bull, S.; Lamka, J.; Skálová, L. Benzimidazole drugs and modulation of biotransformation enzymes. Res. Vet. Sci. 2004, 76, 95-108.

10. Janupally, R.; Jeankumar, V.U.; Bobesh, K.A.; Soni, V.; Devi, P.B.; Pulla, V.K.; Suryadevara, P.; Chennubhotla, K.S.; Kulkarni, P.; Yogeeswari, P.; et al. Structure-guided design and development of novel benzimidazole class of compounds targeting DNA gyraseB enzyme of Staphylococcus aureus. Bioorg. Med. Chem. 2014, 22, 5970-5987.

11. Ke, Y.; Zhi, X.; Yu, X.; Ding, G.; Yang, C.; Xu, H. Combinatorial synthesis of benzimidazole-azo-phenol derivatives as antifungal agents. Comb. Chem. High Throughput Screen 2014, 17, 89-95. 
12. Tonelli, M.; Paglietti, G.; Boido, V.; Sparatore, F.; Marongiu, F.; Marongiu, E.; La Colla, P.; Loddo, R. Antiviral activity of benzimidazole derivatives. I. Antiviral activity of 1-substituted-2[(benzotriazol-1/2-yl)methyl]benzimidazoles. Chem. Biodivers. 2008, 5, 2386-2401.

13. Vitale, G.; Corona, P.; Loriga, M.; Carta, A.; Paglietti, G.; Ibba, C.; Giliberti, G.; Loddo, R.; Marongiu, E.; la Colla, P. Styrylbenzimidazoles. Synthesis and biological activity-Part 3. Med Chem. 2010, 6, 70-78.

14. Tonelli, M.; Simone, M.; Tasso, B.; Novelli, F.; Boido, V.; Sparatore, F.; Paglietti, G.; Pricl, S.; Giliberti, G.; Blois, S.; et al. Antiviral activity of benzimidazole derivatives. II. Antiviral activity of 2-phenylbenzimidazole derivatives. Bioorg. Med. Chem. 2010, 18, 2937-2953.

15. Vitale, G.; Corona, P.; Loriga, M.; Carta, A.; Paglietti, G.; Giliberti, G.; Sanna, G.; Farci, P.; Marongiu, M.E.; la Colla, P. 5-Acetyl-2-arylbenzimidazoles as antiviral agents. Part 4. Eur. J. Med. Chem. 2012, 53, 83-97.

16. Tonelli, M.; Novelli, F.; Tasso, B.; Vazzana, I.; Sparatore, A.; Boido, V.; Sparatore, F.; la Colla, P.; Sanna, G.; Giliberti, G.; et al. Antiviral activity of benzimidazole derivatives. III. Novel anti-CVB-5, anti-RSV and anti-Sb-1 agents. Bioorg. Med. Chem. 2014, 22, 4893-4909.

17. Shingalapur, R.V.; Hosamani, K.M.; Keri, R.S.; Hugar, M.H. Derivatives of benzimidazole pharmacophore: Synthesis, anticonvulsant, antidiabetic and DNA cleavage studies. Eur. J. Med. Chem. 2010, 45, 1753-1759.

18. Siddiqui, N.; Andalip; Bawa, S.; Ali, R.; Afzal, O.; Akhtar, M.J.; Azad, B.; Kumar, R. Antidepressant potential of nitrogen-containing heterocyclic moieties: An updated review. J. Pharm. Bioallied Sci. 2011, 3, 194-212.

19. Datar, P.A.; Limaye, S.A. Design and Synthesis of Mannich bases as Benzimidazole Derivatives as Analgesic Agents. Anti-Inflamm. Anti-Allergy Agents Med. Chem. 2015, 14, 35-46.

20. Achar, K.C.S.; Hosamani, K.M.; Seetharamareddy, H.R. In vivo analgesic and anti-inflammatory activities of newly synthesized benzimidazole derivatives. Eur. J. Med. Chem. 2010, 45, 2048-2054.

21. Bansal, Y.; Silakari, O. The therapeutic journey of benzimidazoles: A review. Bioorg. Med. Chem. 2012, 20, 6208-6236.

22. Cho, H.S.; Lopes, P.F. Injectable Formulation of a Macrocyclic Lactone and Levamisole. (2011): United States Patent NO. 20130090296. Available online: http://patentscope.wipo.int/search/en/ detail.jsf?docId=WO2011161209\&recNum=34\&maxRec=497\&office=\&prevFilter=\&sortOption $=\&$ queryString=DORAMECTIN\&tab=PCTDescription (accessed on 10 June 2015).

23. Stefanska, J.Z.; Gralewska, R.; Starosciak, B.J.; Kazimierczuk, Z. Antimicrobial activity of substituted azoles and their nucleosides. Pharmazie 1999, 54, 879-884.

24. Valdez, J.; Cedillo, R.; Hernández-Campos, A.; Yépez, L.; Hernández-Luis, F.; Navarrete-Vázquez, G.; Tapia, A.; Cortés, R.; Hernández, M.; Castillo, R. Synthesis and antiparasitic activity of 1H-benzimidazole derivatives. Bioorg. Med. Chem. Lett. 2002, 12, 2221-2224.

25. Desai, N.C.; Kotadiya, G.M. Microwave-assisted synthesis of benzimidazole bearing 1,3,4-oxadiazole derivatives: Screening for their in vitro antimicrobial activity. Med. Chem. Res. 2014, 23, 4021-4033.

26. Kishore Babu, P.N.; Ramadevi, B.; Poornachandra, Y.; Ganesh Kumar, C. Synthesis, antimicrobial, and anticancer evaluation of novel 2-(3-methylindolyl)benzimidazole derivatives. Med. Chem. Res. 2014, 23, 3970-3978. 
27. Phillips, M.A. CCCXVII.-The formation of 2-substituted benziminazoles. J. Chem. Soc. (Resumed) 1928, doi:10.1039/JR9280002393.

28. Dirk, S.; Thorsten, L.L.; Philipp, L.; Martin, L.; Ralf, R.H.L.; Kirsten, A.; Klaus, R.; Gerald Juergen, R.; Stephan Georg, M. Alkyne compounds with $\mathrm{MCH}$ antagonistic activity and medicaments comprising these compounds. (2009), Boehringer Ingelheim Pharma GmbH and Co. KG: United States Patent Patent no. US 7592358 B2. Available online: http://www.lens.org/lens/patent/US_7592358_B2/ fulltext (accessed on 10 May 2015).

29. Tavman, A.; Ikiz, S.; Bagcigil, A.F.; Ozgur, N.Y.; Ak, S. Preparation, characterization and antibacterial effect of 2-methoxy-6-(5-H/Me/Cl/ $\mathrm{NO}_{2}-1 H$-benzimidazol-2-yl)phenols and some transition metal complexes. J. Serbian Chem. Soc. 2009, 74, 537-548.

30. Podunavac-Kuzmanovic, S.O.; Cvetkovic, D.M. Antibacterial evaluation of some benzimidazole derivatives and their zinc(II) complexes. J. Serbian Chem. Soc. 2007, 72, 459-466.

31. Karuvalam, R.P.; Haridas, K.R.; Shetty, S.N. Trimethylsilyl chloride-catalyzed synthesis of substituted benzimidazoles using two phase system under microwave conditions, and their antimicrobial studies. J. Chil. Chem. Soc. 2012, 57, 1122-1125.

32. González-Chávez, M.M.; Méndez, F.; Martínez, R.; Pérez-González, C.; Martínez-Gutiérrez, F. Design and Synthesis of Anti-MRSA Benzimidazolylbenzene-sulfonamides. QSAR Studies for Prediction of Antibacterial Activity. Molecules 2011, 16, 175-189.

33. Bauer, R.W.; Kirby, M.D.K.; Sherris, J.C.; Turek, M. Antibiotic susceptibility testing by standard single disc diffusion method. Am. J. Clin. Pathol. 1966, 45, 493-496.

Sample Availability: Samples of the compounds are not available from the authors.

(C) 2015 by the authors; licensee MDPI, Basel, Switzerland. This article is an open access article distributed under the terms and conditions of the Creative Commons Attribution license (http://creativecommons.org/licenses/by/4.0/). 